\title{
Content Transformation of Improvement of Qualification of the Teachers of Philological Disciplines in the Kherson Region (1944-1958)
}

\author{
Kuzmenko Vasily \\ ORCID http://orcid.org/0000-0002-5424-8234 \\ Kherson Academy of Continuing Education Municipal Higher Education \\ Institution, Doctor of Pedagogical Sciences, Professor (Ukraine, Kherson)
}

\author{
Chukh Ganna \\ ORCID http://orcid.org/0000-0002-6831-4204 \\ Applicant at the Department of Department of Pedagogy and Education \\ Management, Kherson Academy of Continuing Education Municipal Higher \\ Education Institution
}

\begin{abstract}
The article on the basis of archival materials reveals the peculiarities of the formation of the system of advanced teacher's training of philological disciplines of the South of Ukraine in 1944-1958, in particular in the Kherson region. It is established that in the studied historical period the determining factor of this educational branch was the focus on updating the content of education, based on veiled russification, ideologization of language and literature education in the region without taking into account the polyethnic composition of the population. Analysis of archival data reflecting the results of the system in this period, gave an opportunity to determine the specific features of this period, potential, results and existing contradictions, made it possible to identify positive trends that are relevant for extrapolating the experience of postgraduate education of teachers of philological disciplines in southern Ukraine, in particular in the Kherson region, in the modern educational space.
\end{abstract} South of Ukraine.

Key words: postgraduate education, philological disciplines, system of advanced training, teachers, the

Актуальність дослідження. У контексті нашого дослідження ми відстежимо трансформацію змісту системи підвищення кваліфікації вчителів філологічних дисциплін на Півдні України, зокрема в Херсонській області, у 1944-1958 рр. через призму архівних документів, що відображають діяльність цієї освітньої галузі. Основу джерельної бази становлять архівні матеріали Державного архіву Херсонської області, деякі з них залучені до наукового обігу вперше.

Виклад основного матеріалу. Певні аспекти досліджуваної проблеми можна віднайти в працях українських науковців. Нами здійснено аналіз історико-педагогічних пошуків Крисюка С. В. [4], Кузьмінського А. І. [6], Слюсаренко Н. В. [13; 14] та ін. У цих дослідженнях розкрито основні тенденції розвитку й функціювання означеної 
освітньої галузі в різні періоди, у тому числі й у 1944-1958 рр., однак недослідженим залишається відстеження змін у процесі формування змісту підвищення кваліфікації вчителів філологічних дисциплін на Півдні України на прикладі діяльності конкретного закладу підвищення кваліфікації педагогів означеного періоду - Херсонського обласного інституту удосконалення вчителів (ОІУВ). Саме в цьому й полягає наукова новизна публікації.

За архівними даними, починаючи з 1944 року, в ОІУВ УРСР, зокрема в такий освітній заклад у Херсоні, було надіслано збірник керівних матеріалів про школу, виданих Народним комісаріатом РРФСР. Очевидно, що за таких підходів ідея врахування регіональних особливостей функціювання цієї освітньої галузі навіть не обговорювалася: цей процес відображав загальнодержавні й всеукраїнські тенденції змісту післядипломної освіти. Зокрема, рекомендованими для пропагування серед педагогів були постанова Ради народних комісарів РРФСР № 671 від 23.07.1943 р. «Про введення роздільного навчання хлопчиків і дівчаток у неповних середніх і середніх школах обласних, крайових міст, столичних центрів автономних республік і великих промислових міст» [2, арк. 3], наказ Наркому освіти РРФСР №162 від 16.09.1943 року «Про покращення контролю за роботою шкіл і вчителів і організацією обліку знань учнів», який передбачав «розроблення системи заходів 3 підвищення педагогічної кваліфікації...» [там само, арк. 11] тощо.

На нашу думку, показовим є той факт, що хронологічне відстеження архівних документів Херсонського ОІУВ підтверджує: уже через рік після зазначеного вище транслювання для вчителів ідей Наркому освіти РРФСР у 1944-1945 роках у заклад надходять інструктивні матеріали за підписом народного комісара освіти (чи його заступника) УРСР. Зокрема, для вчителів філологічних дисциплін у 1944 р. - це «Вказівки про святкування в школах УРСР сторіччя з дня смерті великого російського байкаря І. А Крилова» [1]. Інструкції та вказівки орієнтували цю категорію педагогів на вивчення творів російської літератури, нівелюючи твори світової літературної класики, на вивченні творчості українських письменників не наголошувалося в нормативних документах галузі народної шкільної освіти.

3 січня 1945 р. почав виходити науково-педагогічний журнал «Радянська школа». У вказівці Наркому освіти УРСР для педагогів, у тому числі й для херсонських 
вчителів, відзначено, що це видання містить статті на актуальні теми теорії, історії педагогіки, психології та методики викладання окремих дисциплін і всієї практичної методичної роботи [10]. Використання цієї грунтовної та всебічної інформації про концептуальні засади розвитку освітньої галузі стало поштовхом для створення вже працівниками Херсонського ОІУВ методичних рекомендацій для вчителів філологічних дисциплін. Зокрема, такі вказівки «Повторення пройденого з української мови в 7-10 класах» мали практичне спрямування й містили зразки пов'язування повторення орфографічного матеріалу з викладом нових тем, рекомендації щодо використання вивченого в початковій школі [3].

Отже, цитовані документи дають можливість відстежити трансформацію змісту підвищення кваліфікації вчителів філологічних дисциплін в Херсонській області: від буквального виконання постанов і наказів Ради народних комісарів і Міністерства просвіти РРСФСР до використання в роботі вказівок Народного комісара освіти УРСР та матеріалів всеукраїнського видання для освітян, і далі - до формування змісту означеної освітньої галузі з урахуванням регіональних запитів педагогів, хоч ці заклади у своїй роботі відображали загальнодержавні й всеукраїнські тенденції змісту післядипломної освіти. Цю думку підтверджено й подальшим хронологічним переліком архівних справ, що фіксують діяльність Херсонського ОІУВ та методичних служб області: річний і піврічний звіти райпедкабінетів за 1948-1949 н.р. [12], річний звіт Херсонського ОІУВ за 1953 р. [11], плани роботи ради інституту і звіти завкабінетами і методистів про наукові відрядження 1954-1955 н.р [7] тощо. Окрім того, 31946 р. розпочався новий наступ на національну школу. Стан українізації шкільної освіти пішов у зворотному напрямку: кількість шкіл із російською мовою навчання починає збільшуватися, а кількість шкіл з українською мовою навчання зменшується [5, c. 250$]$.

У документах, що містять аналіз діяльності цих складових підвищення кваліфікації вчителів, чітко визначено напрацювання і недоліки в мовно-літературній освіті Херсонської області цього періоду. Зокрема, відзначено, що для вчителів російської мови «забезпечено подальше підвищення ідейно-політичного рівня, надана методична допомога, особливо молодим учителям-початківцям» [11]. Ця цитата дослівно дублює Положення про ОІУВ, що ще раз підтверджує тезу про те, що подібні 
освітні заклади у своїй роботі відображали загальнодержавні й всеукраїнські тенденції змісту підвищення кваліфікації педагогів. 3-поміж іншого, відзначено, що для цієї категорії вчителів проведено 9 семінарів, працівниками ОІУВ відвідано 128 уроків російської мови, надано 200 консультацій, розроблено методичні рекомендації щодо впровадження передового педагогічного досвіду, роботи 3 молодими вчителями; здійснено аналіз підручників «Російська мова» Фінкеля і Баженова для шкіл 3 українською мовою навчання (I i II частини), аналіз навчальних програм; надано рецензії на статті з методики викладання російської мови в журналі «Радянська школа» за 1952 рік [там само, арк. 25].

Цей же документ фіксує зростання професійності цієї категорії вчителів: вони вже «не допускають зловживання історичними екскурсами в минуле, що завдавало збитків міцному засвоєнню граматики сучасної російської мови» [11, арк. 34]. Серед зазначених недоліків - той факт, що «частина вчителів нашої області, особливо ті, які не мають відповідної підготовки, не завжди правильно науково викладають шкільний граматичний матеріал. Ці вчителі мало готуються до уроків, не цікавляться методичною літературою [там само, арк. 36]. Зазначені недоліки пояснюють такими причинами: фахівці «не відповідають тим вимогам, що тепер визначені для словесників; вони не мають в достатній кількості методичної літератури; райони не мають у достатній кількості кваліфікованих учительських кадрів словесників, у низці районів викладають російську мову вчителі, які не мають спеціальної освіти» [там само, арк. 47].

Значно меншим за обсягом є звіт Херсонського ОІУВ щодо аналізу фахової майстерності й напрямів підвищення кваліфікації вчителів української мови, іноземної мови. Зокрема, з-поміж іншого, зазначено, що складено й розіслано «примірний план роботи методичного об'єднання вчителів української мови». 3 недоліків указано на «формалізм у низки викладачів: вони не прагнуть виховувати марксистський світогляд на уроках мови» [11, арк. 83]. Звіт про роботу підвищення кваліфікації вчителів іноземної мови вкрай заідеологізований. До речі, про викладання англійської мови в школах в документі згадується лише принагідно, у переліку іноземних мов, які викладаються в школах області. Натомість є інформація про «перебудову викладання німецької мови у світлі вчення тов. Сталіна про мову»; у пропонованому плані роботи методичного об’єднання вчителів німецької мови - доповідь «Учення Сталіна про 
граматичну будову мови і роль граматики в системі викладання іноземної мови» [там само, арк. 95].

Висновки. Таким чином, зміни в процесі формування змісту підвищення кваліфікації вчителів філологічних дисциплін на Півдні України на прикладі діяльності Херсонського ОІУВ спрямовані на пошук оптимальної моделі, яка відображала загальнодержавні й всеукраїнські тенденції змісту післядипломної освіти. Для підвищення результативності цього процесу застосовувалися всі наявні ресурси цієї освітньої галузі, хоч уся їхня діяльність підпорядковувалася ОІУВ. Крім цього, іiі діяльність була спрямована на оновлення змісту освіти, що грунтувалося на завуальованій росіянізації, ідеологізації мовно-літературної освіти регіону в досліджуваний період.

\section{References}

1. Vkazivki pro svyatkuvannya $v$ shkolah URSR storichchya $z$ dnya smerti velikogo rosijskogo bajkarya I.A.Krylova. [Instructions on the celebration in the schools in URSR the centenary of the death of the best-known Russian fabulist I. A Krylov] // Derzhavnij arhiv Hersonskoyi oblasti (DAHO). F.R. 2419. Op. 1. Spr.9. 3 p.

2. Metodicheskie razrabotki Ministerstva prosveshchenija [Methodological materials of the Ministry of Education] // DAKhO. F.R. 2419. Op. 1. Spr.3. 165 p.

3. Metodichni rekomendaciyi «Povtorennya projdenogo z ukrayinskoyi movi v 7-10 klasah» Hersonskogo OIUV. [Methodological recommendations "Repetition of passed in the Ukrainian language in grades 7-10" of Kherson OIUV] // DAKhO. F.R. 2419. Op. 1. Spr. $15 \mathrm{p}$.

4. Krisyuk S.V. Rozvitok pislyadiplomnoyi osviti pedagogichnih kadriv v Ukrayini (1944-1995 rr.): monografiya [Development of postgraduate education of pedagogical staff in Ukraine (1944-1995): monograph]/ L'viv, 1997. 206 p.

5. Kuzmenko V.V. Formuvannya naukovoyi kartyny svitu uchniv: vid vytokiv do sogodennya: monografiya [The formation of a scientific picture of the world of students: from beginnings to the present]. Tretye vy`dannya pereroblene i dopovnene/ V.V Kuz menko. Kherson, $679 \mathrm{p}$.

6. Kuz'minskij A. I. Teoretiko-metodologichni zasadi pislyadiplomnoyi pedagogichnoyi osviti v Ukrajini (1944-1995rr.) [Theoretical and methodological tasks of postgraduate pedagogical education in Ukraine (1944-1995)]: dis. ... d-ra ped.nauk: 13.00.04. Kyiv, 2003. 481 p.

7. Pet`ko L.V. Na shlyachu perebudovy [On the way of rebuilding]. Rad. shkola. 1987. No. 11. P. 60-65.

8. Pet'ko L.V. Realizacija neperervnoi' movnoi' osvity $u$ VNZ Ukrai'ny [Implementation of lifelong language learning in high school of Ukraine] // S'omi jurydychni 
chytannja «Kul'tura i pravo na pochatku HHI stolittja»: mat. mizhnar. nauk. konf. Kyiv: Vydvo NPU im. M. P. Dragomanova, 2011. C. 436-438.

9. Plani roboti radi institutu $i$ zviti zavkabinetami $i$ metodistiv pro naukovi vidryadzhennya 1954-1955 n.r. [Work plans of the institute council and reports of heads of offices and methodologists on scientific business trips 1954-1955] // DAKhO. F.R. 2419. Op. 1. Spr. 71.238 p.

10. Pro vikoristannya zhurnalu «Radyans'ka shkola» [About using the magazine «Soviet school»] // DAKhO. F.R. 2419. Op. 1. Spr. 14. 3 p.

11. Richnij zvit Hersons'kogo OIUV za 1953 r. [Annual report of Kherson OIUV for 1953] // DAKhO. F.R. 2419. Op. 1. Spr. 58. 158 p.

12. Richnij i pivrichnij zviti rajpedkabinetiv za 1948-1949 n.r. [Annual and semiannual report of district pedagogical offices for 1948-1949] // DAKhO. F.R. 2419. Op. 1. Spr. 24. $158 \mathrm{p}$.

13. Sliusarenko N. V. Formy I metody vyhovnoii roboty u vyshchomu navchalnomu zakladi [Forms and methods of extracurricular activites in a higher educational institution]. Tavriiskyi visnyk osvity. No 3 (27). 2009. P. 107-116.

14. Sliusarenko N. V., Kokhanovska O. V. Transformatsiia vyshchoi zhinochoi osvity v Ukraini (XIX - pochatok XXI stolittia) [The transformation of higher female educationin Ukraine (XIX - the beginning of the XXI century)]. Visnyk Cherkaskoho universytetu (Seriia Pedahohichni nauky). 2018. Issue 2. P. 124-130.

\section{Translation of the Title, Abstract and References to the Author's Language}

УДК 378.046-021.68:80 (477.7)

Кузьменко Василь, Чух Ганна. Трансформація змісту підвищення кваліфікації вчителів філологічних дисциплін у Херсонській області в період 19441958 pp.

У статті на основі регіональних архівних матеріалів розкрито особливості становлення системи підвищення кваліфікації вчителів філологічних дисциплін Півдня України в 1944-1958 pp. - період становлення радянської системи підвищення кваліфікації педагогів, зокрема в Херсонській області. Установлено, що в досліджуваний історичний період визначальним чинником діяльності означеної освітньої галузі була спрямованість на оновлення змісту освіти, що грунтувалося на завуальованій росіянізації, ідеологізації мовно-літературної освіти регіону. Аналіз нормативних галузевих документів і практичних результатів функціювання закладу, що зібрані в Державному архіві Херсонської області, дав можливість визначити специфічні риси цього періоду, потенціал, результати і наявні суперечності та позитивні тенденції, що $\epsilon$ актуальним для екстраполяції досвіду в сучасний освітній простір.

Ключові слова: післядипломна освіта, філологічні дисципліни, система підвищення кваліфікації, вчителі, Південь України. 


\section{Jimepamypa}

1. Вказівки про святкування в школах УРСР сторіччя 3 дня смерті великого російського байкаря I. А Крилова // Державний архів Херсонської області (ДАХО). Ф.Р. 2419. Оп. 1. Спр.9. - 3 арк.

2. Методические разработки Министерства просвещения // ДАХО. Ф.Р. 2419. Оп. 1. Спр.3. 165 арк.

3. Методичні рекомендації «Повторення пройденого з української мови в 7-10 класах» Херсонського ОІУВ // ДАХО. Ф.Р. 2419. Оп. 1. Спр. 15. 7 арк.

4. Крисюк С. В. Розвиток післядипломної освіти педагогічних кадрів в Україні (1944-1995 рр.): монографія. Львів, 1997. 206 с.

5. Кузьменко В. В. Формування наукової картини світу учнів: від витоків до сьогодення: монографія. 3-є вид., перереб. і доп. Херсон, 2020. 679 с.

6. Кузьмінський А. І. Теоретико-методологічні засади післядипломної педагогічної освіти в Україні (1944-1995 рр.): дис. ... д-ра пед.наук: 13.00.04. Київ, 2003. 481 с.

7. Плани роботи ради інституту і звіти зав кабінетами і методистів про наукові відрядження 1954-1955 н.р. // ДАХО. Ф.Р. 2419. Оп. 1. Спр. 71. 238 арк.

8. Петько Л. В. На шляху перебудови. Рад.школа. 1987. № 11. С. 60-65.

9. Петько Л.В. Реалізація неперервної мовної освіти у ВНЗ України // Сьомі юридичні читання «Культура і право на початку XXI століття»: мат. міжнар. наук. конф. Київ: Вид-во НПУ ім. М. П. Драгоманова, 2011. С. 436-438.

10. Про використання журналу «Радянська школа» // ДАХО. Ф.Р. 2419. Оп. 1. Спр. 14. 3 арк.

11. Річний звіт Херсонського ОІУВ за 1953 р. // ДАХО. Ф.Р. 2419. Оп. 1. Спр. 58. 158 арк.

12. Річний і піврічний звіти райпедкабінетів за 1948-1949 н.р. // ДАХО. Ф.Р. 2419. Оп. 1. Спр. 24. 158 арк.

13. Слюсаренко Н. В. Форми і методи виховної роботи у вищих навчальних закладах. Таврійський вісник освіти. 2009. №3(27). С. 107-116.

14. Слюсаренко Н. В., Кохановська О. В. Трансформація вищої жіночої освіти в Україні (XIX - початок XXI століття). Вісник Черкаського університету (Серія Педагогічні науки). 2018. Вип. 2. С. 124-130. 